\title{
Impact of ecosystem services on a sustainable business strategy in urban conditions
}

\author{
Elena Balashova ${ }^{1}$, and Sabina Sharipova ${ }^{1, *}$ \\ Peter the Great St.Petersburg Polytechnic University, Polytechnicheskaya, 29, St. Petersburg, \\ 195251, Russia
}

\begin{abstract}
The article analyzes the relevance and state of the theory of ecosystem services. A solution for achieving sustainable development goals through the use of ecosystem services in industrialization is proposed. Cases of enterprises British American tobacco, Nestlé Waters, Watershed Agricultural Council, Bain \& Company, McKinsey \& Company, The Starbucks on the application of ecosystem services are considered. A link has been established between public-private partnerships in the provision of ecosystem services. Tendencies of development of ecosystem services in Russia and abroad are defined. Recommendations for companies that have started creating ecosystem services are presented.
\end{abstract}

\section{Introduction}

The significance of the sustainability of major urban systems is determined to the influence of megacities on modern socio-economic development. The UN conference on sustainable development goals (New York, September 2015) identified issues related to urban development, urbanization and industrialization: «Make cities inclusive, safe, resilient and sustainable», «Build resilient infrastructure, promote sustainable industrialization and foster innovation» [1]. Additionally relevant objectives in the development of cities can be identified: «Ensure access to water and sanitation for all», «Ensure sustainable consumption and production patterns», "Sustainably manage forests, combat desertification, halt and reverse land degradation, halt biodiversity loss» [2]. From other point, environmental pollution, namely air pollution, re-use of wastewater, use of chemicals, construction of roads and houses, ionizing and ultraviolet radiation, leads to a reduction in the population, as indicated in table 1 [3]. Business is expressing concern about the deterioration of the environment, which can adversely affect the growth prospects of companies and cause additional risks. Therefore, one of the solutions for stabilizing urban systems and achieving the goals and objectives of sustainable development of the world can be the provision of ecosystem services by enterprises. Classical economic study in the field of identification and economic valuation of ecosystem services is the work of Costanza R. with colleagues [4]. Ecosystem services are interpreted as material, energy and information flows generated by natural capital stocks that, when combined with physical and human capital, ensure the

\footnotetext{
*Corresponding author: sharipovasab@gmail.com
} 
well-being of humanity. Foreign researchers pay attention to methods of ecosystem services assessment and offer practical recommendations [5-7].

Table 1. Number of deaths related to environmental pollution in the world.

\begin{tabular}{|c|c|}
\hline Region & Number, million people \\
\hline South-East Asia & 3.8 \\
\hline The Western part of the Pacific ocean & 3.5 \\
\hline Region of Africa & 2.2 \\
\hline European region & 1.4 \\
\hline Eastern Mediterranean & 0.854 \\
\hline American region & 0.847 \\
\hline
\end{tabular}

In Russia, the initiative to assess ecosystem services is shown by disparate research teams [ $8-10]$, the results of which do not come into practice, since there is no institutional framework. The state is still away from the process of assessing ecosystem services, which are so important for preserving the health of natural ecosystems [11].

Based on the above reasons, the main goal of the work is to study the impact of ecosystem services on the strategy of sustainable business development in urban conditions, the main method is analysis of the world practices of ecosystem services and the possibility of their application in Russian circumstances. For achieving the goal it is necessary to solve the following objectives:

- To study the theory of ecosystem services;

- To identify the best examples of ecosystem services;

- To identify trends in the development and application of ecosystem services in Russia and abroad.

\section{Materials and methods}

Ecosystem services are all the benefits that mankind receives from ecosystems [12]. According to the UN program «Millennium Ecosystem Assessment» services are divided into four types:

1. Supply services - the material benefits that people derive from ecosystems, such as water, food, fibre, timber and fuel.

2. Support services - necessary for the production of all other ecosystem services, such as the provision of livelihoods for plants and animals, species diversity and genetic diversity.

3. Regulation services - benefits obtained from regulation of ecosystem processes, including regulation of air quality and soil fertility, control floods and diseases or pollination of agricultural crops.

4. Cultural services - non - material benefits people obtain from ecosystems, for example, for aesthetic and inginiringovaya inspiration, cultural identity and spiritual wellbeing.

Service providers can be subjects of economy that produce or maintain current levels of ecosystem services. Consumers of ecosystem services are entities that benefit from the use of the service and are willing to pay for it. Payments for ecosystem services-compensation 
paid to ecosystem service providers by their consumers. The use of ecosystem services creates additional opportunities for development of enterprises [13]:

- Reduction of production costs due to the introduction of resource-saving technologies;

- Creation and promotion of new eco-friendly products and services;

- Development of projects and management models to reduce the negative impact on the environment;

- Reduction of risks associated with environmental exposure.

The value of ecosystem services is usually not reflected in market prices, with rare exceptions, such as tourism services. This is mainly due to the fact that many ecosystem services are «common goods» that accessible to all and consumed without competition. In addition, the benefits are perceived differently by people in different places and over different periods of time. These decisions may also be taken at the expense of local public interest in favour of private commercial interests, even when there is a risk of loss of livelihood for the local population. Such decisions may also be made on the basis of shortterm benefits at the expense of benefits sustained over a long-term period. This systemic underestimation of ecosystem services, as well as the lack of mechanisms to measure and record the cost of such services, is one of the main causes of modern environmental challenges.

Enterprise management strategies often include public-private partnerships and stakeholder engagement. This practice can be extended to the creation of ecosystem services. Some companies have separate programs to preserve biodiversity, promote the environment and economic development.

In Russia, the issue of ecosystem services is only beginning to be observes in narrow scientific circles. There is no practice and cannot be due to the lack of support from the government. State support through financing and legislative consolidation stimulates increased public interest in ecosystem services and inter-sectoral cooperation. Potentially ecosystem services can be provide be multinational companies, as corporate activities and ethics of conducting business are regulated by the international standards. Foreign practice of companies shows that successful implementation of ecosystem services allows to develop regions, contribute to the development of society and solve global problems. There are some business cases are reviewed.

British American tobacco company operates according to the principles of sustainable development. The company's administration recognizes that risk management issues can be addressed through through collaborative, cross-sector solutions, involving all the community's stakeholders and covering the whole landscape. For example, in 2016 the was launched program «Sustainable agriculture and farmer livelihoods programme» to all BATowned and strategic third-party suppliers worldwide. The program is based on the worldfamous five 'Capitals', affecting the sphere: financial, natural, human, physical and social factors, which are key to sustainable and thriving agricultural communities. Thrive assessments have been completed in 2016 and 2017 for approximately 250,000+ farmers who supply 17 leaf operations and six strategic third-party leaf suppliers (covering nearly $80 \%$ of total tobacco leaf purchases) [14]. Suppliers complete a comprehensive annual selfassessment around four key pillars: crop, environment, people and facilities, which cover issues such as sustainable water, soil, biodiversity and forest management, safe working conditions, and preventing child and forced labour. They should also demonstrate that they have good governance at the core of all four components and are able to agree on the assessment, identification and mitigation of any significant risks that arise. The event was so successful that at the present time British American tobacco uses this system in establishing new partnership agreements with suppliers and stakeholders.

The company also carries out activities to improve the conditions for its suppliers and the local population, which is a clear example of the provision of ecosystem services. In 
Mexico, the company introducing technologies such as drip irrigation, which has been shown to increase water usage efficiency by up to $90 \%$, as well as reducing soil erosion and salination, and ultimately boosting yields. In Pakistan, in partnership with provincial governments, the company have provided over 6,000 people in remote rural villages with access to solar energy, and have also installed a new water irrigation system for farmers [15].

An example of successful cooperation between companies, the government and the local community is Nestlé Waters. The company operates in accordance with the internal standards of social responsibility. The main goals are: to enable healthier and happier lives through helping 50 million children lead healthier lives; to help develop thriving, resilient communities through improving 30 million livelihoods in communities directly connected to business activities; to steward resources for future generations that include striving for zero environmental impact in operations [16]. The company established the CSV Prize to reward initiatives that reflect the spirit of Creating Shared Value. They look for innovative projects, programs or businesses that have already been tested either as a pilot study or at a small scale, that demonstrate positive social and environmental impact; and that need support to become commercially viable. Agro-Hub is an agricultural production and marketing agency in south-west Cameroon, working to connect smallholder farmers with sustainable markets. It has built a small integrated factory to transform cassava, a staple crop in Cameroon, into starch and garri, a type of tapioca, and sell these value-added goods to consumers through its own fresh food store (Agro-Mart). The agency has helped more than 700 farmers increase productivity and income as they build long-term sustainable relationships with buyers. Agro-Hub received a prize of CHF 300000, which it intends to use for upgrading its cassava processing facilities [17]. This increase in production capacity will allow it to support more farmers, and contribute to improved food security and living conditions.

Another case of Nestlé Waters is the PES program developed and implemented by brand Vittel in north-eastern France. The objective of the PES program was to provide a high level of water quality, specifically nitrate rates below $4.5 \mathrm{mg} / 1$ in the aquifer. This required maintaining a rate of $10 \mathrm{mg} / 1$ in the root zone of the plants, which is achieved by reducing fertilizer use, animal waste and manure application and making use of the capacity of the soil to absorb nitrates [18]. Vittel proposed to farmers in 1988 to transform their intensive dairy farming system into extensive, hay-based dairy farming with no pesticides and chemicals. The buyer of the ecosystem service is Nestlé Waters, through its intermediary Agrivair, sellers are the farmers active. The key terms of collaboration were [19]:

- Long term security through 18 - or 30-year contracts;

- Subsidy of, on average, about 200 euros/ha/year over five years. This is to ensure a guaranteed income during the transition period and reimburse the debt contracted before entering the program for the acquisition of farm equipment;

- Up to 150,000 euros per farm to cover the cost of all new farm equipment and building modernization;

- Free labour to apply compost in farmers' fields;

- Free technical assistance including annual individual farm plans and introduction to new social and professional networks.

By 2004, all 26 farms in the area had adopted the new farming system, 1,700 ha of maize had been eliminated; and $92 \%$ of the sub-basin was protected [20]. A clear indicator of success has been the request from young farmers who have taken over the family farm to enter into 30-year contracts. At present, all farmers have signed 30-year contracts.

The next case of ecosystem service is activity of the Watershed Agricultural Council which is funded in part by New York City Environmental Protection, the U.S. Department 
of Agriculture, the U.S. Forest Service and other federal, foundation and private sources. It works with farm and forest landowners in the New York City Watershed region to protect water quality on behalf of nine million New York residents. One of the programs of WAC is «Whole Farm Planning» - a holistic approach to farm management used to identify and prioritize environmental issues on a farm without compromising the farm business. Potential water risks have been addressed through careful structural planning to reduce or avoid the transfer of runoff to streams in the farm. This is important because this water eventually enters the reservoir in New York city. The process begins when a farmer signs a voluntary participation agreement with WAC and agrees to develop a Whole Farm Plan in conjunction with a Planning and Implementation Team. Each team is multidisciplinary, and may have representatives from the USDA Natural Resources Conservation Service, Cornell Cooperative Extension and county Soil and Water Conservation Districts [21]. Once a landowner voluntarily agrees to sell or donate certain rights or uses associated with a property via a conservation easement, the private organization or public agency that holds the conservation easement is obligated to enforce the landowner's promise not to exercise those rights and follow the terms and conditions of the conservation easement [22].

Other example of ecosystem service is program of Bain \& Company. The company helps to solve some of the world's most complex social problems by working with innovative non-profit organizations focused on changing government structures and leading private sector companies. In partnership with an established community organization, Bain established a new charter school in Chicago's greatly underserved West Town neighborhood. Bain case teams worked with school leadership to design and open the school. Utilizing the full Bain toolkit, these teams delivered [23]:

- Best practice research to apply key lessons from the best-performing charter schools nationwide;

- School startup tools to help leadership manage the process;

- Financial model and analysis to help set budgets and sustain growth;

- Assessment analysis tool to help teachers analyze test results and customize instruction;

- Bain also developed a school governance model, teacher training programs, a technology and operations strategy, a student recruitment plan, and much more.

Bain also invest into economic development work leverages the power of markets and business enterprise models to create jobs, fuel income growth and improve the quality of life for the world's poor. Bain supports nonprofits and entrepreneurs who seek to bring growth to the communities they serve in effective and sustainable ways.

Our economic development work focuses on five sub-sectors [24]:

- Entrepreneurship: the copmany partner with Endeavor to support high-impact entrepreneurs and catalyze vibrant, self-sustaining entrepreneurial ecosystems around the world;

- «Social-first» impact investing: Impact investors who scale innovative enterprises that deliver affordable, high-quality, critical services - such as clean energy, healthcare, education and financial services - to the poor.

- Agriculture and livelihood: Organizations that enhance the livelihood of smallholder farmers by strengthening their capacity and integrating them into agricultural supply chains.

- Workforce integration: Organizations that support the development and integration of marginalized groups - such as refugees and disadvantaged youth-into the economy.

- Sustainable development: Innovative environmental nonprofits who work to preserve our world's natural resources.

The next is case of McKinsey \& Company - global management consulting firm that serves a broad mix of private, public and social sector institutions. The company is also committed to social impact through the way it run business. Our expertise spans economic 
development and trade, education and youth empowerment, public health, disaster relief and reconstruction, agriculture and rural development, green growth, power and energy, financial inclusion, migration, and social inclusion [25]. One of the initiatives is agricultural program «Agriculture as an economic engine». A North African country asked McKinsey to help transform agricultural production to stimulate economic growth, create jobs, and alleviate poverty. Among the goals: more than double the income of three million subsistence farmers. Different challenges prevent growing of sphere. So with 75 per cent of farms at less than 12 acres - and an average herd of four cows per farm-fragmented land ownership was a major barrier to the development of an efficient, well-capitalized agricultural sector [26]. McKinsey's team began with talks including officials from the Ministry of agriculture, representatives from other government agencies, agribusiness leaders, economic development experts, and farmers. From this, a comprehensive reform and modernization plan has been drawn up. McKinsey team has conducted in-depth analysis of many potential crops and animals that have competitive advantages in production and are potentially available to export markets. The group calculated that the focus was on those crops that could pave the way for a substantial increase in agricultural exports. The program revolves around larger nucleus farms of 50 hectares or more, on land leased by the government to a commercial farmer. The commercial farmer commits to working with surrounding smallholders, providing access to financing, equipment and expertise in return for the right to market their crops [27]. A new government agency has been created for the management of contracts and for the promotion of the program to potential investors. At the same time the government launched a major effort to improve water resources through greater efficiency and sustainability, with new dams, pipelines, desalination plants, and water recycling. Finally the program would require 10-year management. The Ministry of Agriculture has been restructured, regulations loosened and new trade agreements negotiated. Agricultural exports, identified by McKinsey as one of the keys to a more prosperous farming sector, are on a firmly upward trend [28].

The last is case of The Starbucks company. The company has a successful social responsible strategy and code of conduct that applies to each employee as well as to consultants, agents, contractors and suppliers. The business has several programs that support local community, raise sustainability of environment. In September 2015, Starbucks launched the One Tree for Every Bag program to help ensure the long-term supply of coffee and the economic future of coffee farmers. The goal was to raise enough funds by the end of 2016 to plant 20 million coffee seedlings to replace trees that are declining in productivity due to age and disease, such as coffee leaf rust [29]. This effort was a part of ongoing commitment to provide comprehensive support to farmers around the world which includes open-source agronomy research, farmer financing and access to information.

Another initiative is The Starbucks Global Farmer Fund that include a $\$ 50$ million commitment to provide financing to coffee farmers. It began investing in farmer loans in 2000 , providing access to credit at reasonable terms is a critical aspect of our farmer support model. Our loan partners made loans in 13 countries including Peru, Nicaragua, Honduras, Rwanda, Guatemala, Mexico, Costa Rica, Colombia, Kenya, Uganda, The Democratic Republic of Congo, Tanzania and Indonesia. Loan recipients also receive technical assistance in the form of agronomy best practices, business planning and price risk management training [30].

\section{Results}

The analysis made by the authors allowed to make the following outcomes: 
- Global interest to ecosystem services is increasing. Application practice does not depend on the region;

- In the context of urbanization, the provision of ecosystem services is not limited to the city, but extends to the nearest territories, which force the development of regions;

- Business, government and society benefit directly or indirectly from the use of ecosystem services;

- Implementation of ecosystem services in most cases is carried out through publicprivate partnership;

- The company's commitment to maintaining ecosystems starts with corporate governance and becomes an integral part of all management processes;

- Enterprises that are aware of their influence and dependence on the performance of ecosystems, through the provision of ecosystem services, reduce risks and gain additional profit opportunities.

\section{Discussion}

The world is increasingly focusing on the maintenance and protection of the environment, socio-economic issues and the development of society. The economic significance of the performance properties of ecosystems and provision of ecosystem services in urban environments depend on the demand factors and the main causes of the changes such as economic growth, population growth and urbanization, , political situation, environmental policy, the development of knowledge and technologies and the limitations of the proposal such as climate change, the increasing scarcity of natural resources, decline in the quality of the performance properties of the ecosystem. Therefore, the development of ecosystem services is an urgent need of modern world.

Examples of companies British American tobacco, Nestlé Waters, Watershed Agricultural Council show that solving global problems and achieving sustainable goals is impossible without the cooperation of the state, business, society and stakeholders. The government in such cooperation can act as an investor of programs for the creation of ecosystem services and a controller of their compliance with legal requirements. Society and interested persons can be both suppliers and consumers of ecosystem services, receiving improvement of living conditions, additional workplaces, education. The business receives the goods and services improved on quality, new sales markets, creates positive reputation about the activity.

Business can influence the choice and behavior of consumers, being the main supplier of goods and services. Therefore, representatives of enterprises should take a responsible approach to determining the impact of products on the environment, spreading information about the use and disposal of waste. For achieving that corporate governance must take into account environmental, social and economic development. British American tobacco, Nestlé Waters, whose corporate-social responsibility is developed, train local communities in their areas of operation in order to improve the quality of raw materials and final product, loyalty to the company and support innovative development. The following recomendations can be implemented for companies that have started creating ecosystem services:

- To assess the impact of business on ecosystems and its dependence on them, including direct and indirect linkages throughout the value chain;

- To improve the system of providing information, to develop quantitative performance indicators as well as their integration into broader processes risk assessment and management of business opportunities;

- To look for emerging business opportunities such as economic efficiency, new products and new markets;

- To combine business strategies with broader social responsibility initiatives; 
- To engage colleagues and stakeholders, non-governmental organizations and civil society to improve governance and strategy.

In Russian Federation the development of ecosystem services is possible only with the support of the state. It can provide financial support in the form of: the provision of budget funds (Federal and regional budgets), trade quotas for development or environmental damage, the use of interest-free loans, the provision of tax incentives, the development of new ownership rights to ecosystems and trade schemes. The government can also exercise control over the provision of ecosystem services through the establishment of a methodology for quantifying the impact of industrial enterprises and industries on the exploitation of ecosystem properties and strengthening the legislative framework. Effective control and assurance mechanisms are also needed to confirm the correctness of the business and the quality of the provided information. Additionally, assessing ecosystem services and comparing the benefits of preserving natural systems with the benefits of developing these sites can be useful in setting policy priorities in many situations, such as urban development or environmental planning at the national or local level.

\section{Conclusions}

The theory and practice of ecosystem services is under development. Institutions and instruments for governance have not yet been created, the legislative framework is not developed in all regions of the world, and the issue of economic valuation remains significant. Further development of research is seen in the development of models and methodologies for ecosystem services, taking into account economic, environmental and social factors. For developing research on ecosystem services in urban environments, it is necessary to take into account regional development and the legislative framework.

\section{References}

1. URL : http://www.un.org/sustainabledevelopment/sustainable-development-goals

2. United Nations. Sustainable development goals. URL: http://www.un.org/sustainabledevelopment/sustainable-development-goals

3. World health organizations. The impact of the environment on health. URL: http://www.who.int/quantifying_ehimpacts/publications/PHE-preventiondiseases-infographic-RU.pdf?ua=1.

4. R.Costanza, R. d'Arge, R. de Groot, Nature 387, 253-260 (1997)

5. W. Shang, Y. Gong, Z. Wang, M.J. Stewardson, Journal of Environmental Management 210, 162-170 (2018)

6. S. Schomers, B. Matzdorf, Ecosystem Services 6, 16-30 (2013)

7. S. Hynesa A. Ghermandib, D. Norton, H. Williams, Marine recreational ecosystem service value estimation: A meta-analysis with cultural considerations. Ecosystem Services (2018)

8. V.V. Glukhov, I.V. Ilin, A.I. Levina, Lecture Notes in Computer Science 9247, 543553 (2015)

9. E.S. Balashova, E.A. Gromova, Arctic shelf development as a driver of the progress of the Russian energy system, MATEC Web of Conferences (2017)

10. S.N. Bobylev, V.M. Zakharov, Ekosistemnye uslugi $i$ ekonomika (Tsentr ekologicheskoy politiki Rossii, Russia, 2009)

11. URL:http://www.millenniumassessment.org/documents/document.791.aspx.pdf 
12. URL: http://www.teebweb.org/publication/teeb-for-business-executive-summary

13. URL: www.bat.com/group/sites/uk_ 9d9kcy.nsf/vwPagesWebLive/DOAMNMPK

14. URL: /www.bat.com/group/sites/uk_9d9kcy.nsf/vwPagesWebLive/DOAMNMPK

15. URL:www.nestle.com/asset-library/documents/library/documents/corporate_ social_responsibility/nestle-csv- full-report-2016-en.pdf

16. URL: www.nestle.com/assetlibrary/documents/library/documents/corporate_social_responsibility/nestle-csv-fullreport-2016-en.pdf

17. D. Perrot-Maître, The Vittel payments for ecosystem services: a "perfect" PES case? (International Institute for Environment and Development, London, 2006)

18. Watershed Agricultural Council. URL: https://www.nycwatershed.org/conservationeasements/what-is-a-conservation-easement

19. Bain \& Company. URL: http://www.socialimpactatbain.com/partner-for-impact/localcommunity/rowe.aspx

20. URL: https://www.mckinsey.com/about-us/social-impact

21. URL: https://www.mckinsey.com/industries/social-sector/how-we-helpclients/agriculture-as-an-economic-engine

22. URL: https://www.starbucks.com/responsibility/community/farmer-support/socialdevelopment-investments 